\title{
German Guilt and Hebrew Redemption
}

\author{
Aktion Sühnezeichen Friedensdienste and the Legacy of \\ Left-Wing Protestant Philozionism
}

\section{Introduction}

The history of Aktion Sühnezeichen Friedensdienste (ASF) in Israel constitutes an intriguing point of departure to study the legacy of left-wing Protestant Philozionism within German-Israeli relations. Ever since ASF began sending volunteers to Israel in 1961, the encounter between left-wing Protestant pacifists and the Jewish nation-state produced various forms of converts: converts to Judaism, converts to Zionism, and converts to the Palestinian cause. ${ }^{1}$ While many volunteers chose Israel for the sun, the beach, ${ }^{2}$ and the promise of romantic encounters in the exotic Levant, ${ }^{3}$ few left the region unchanged. The graduates of ASF's Israel program frequently moved on to fill Israel-focused (or Middle East-fo-

The author would like to thank Bernhard Krane, head of the Israel desk at Aktion Sühnezeichen Friedensdienste, for an interview on the topic and for his generous support in researching material for this chapter. Many thanks also to Jenny Hestermann for her advice on locating the Sühnezeichen diaries from the first cohorts and of course to the anonymous reviewer for the detailed and helpful criticism.

1 In the third cohort alone, four volunteers converted to Judaism, "two stayed on in Israel; and all remained strongly pro-Israel”; see Lilach Marom, “'On Guilt and Atonement’: Aktion Sühnezeichen Friedensdienste and Its Activity in Israel,” Yad Vashem Studies 35 (2007): 187-220, here at 196.

2 Harald Martenstein, “Das volle Utopieprogramm,” Tagesspiegel (January 10), 2004, http:// www.tagesspiegel.de/kultur/das-volle-utopieprogramm/480722html (last accessed September 28, 2018).

3 The first bashful hint towards romantic encounters between German volunteers and Israelis is contained in the diary of the first cohort, which explains that native-born Israelis are called "sabras" after the prickly pears, which are prickly on the outside but sweet on the inside - "especially the women, 'according to reports”, Evangelisches Zentralarchiv (EZA) 19/735 [all translations by the author]. Later accounts by Aktion Sühnezeichen volunteers are much more explicit. The third issue of the volunteer journal Memrachit (1986) contains practical advice for female German volunteers on how to escape unwanted male Israeli attention, including "entangling people in political conversations" and "reacting to physical come-ons with a slap in the face,” EZA 19/1868.

○ OpenAccess. () 2020 Aue-Ben-David et al., published by De Gruyter. (cc)BY This work is licensed under the Creative Commons Attribution 4.0 International. https://doi.org/10.1515/9783110664713-015 
cused) positions in the German media, Protestant churches, political foundations, and academia. Both the current president of the German-Arab Society (and a vocal critic of Israel's foreign policy), Michael Lüders, and the late Eike Geisel, a key inspiration for the left-wing pro-Zionist movement known as 'Anti-Germans' (Antideutsche), began their intellectual careers as Aktion Sühnezeichen volunteers in Israel. ${ }^{4}$ Within the Protestant churches, the impact of pastors who served as volunteers in Israel can be felt in the Protestant Middle East Commission (Evangelische Mittel-Ost Kommission), ${ }^{5}$ in the Working Group "Jews and Christians" at the Protestant Church Congress (Evangelischer Kirchentag), ${ }^{6}$ in key policy documents on the Arab-Israeli conflict, including the recent position paper "Promised Land" (Gelobtes Land), ${ }^{7}$ and in the transformation of Israel Sunday (Israelsonntag) from an obscure remainder of supersessionism and the Protestant missions to the Jews into a yearly celebration of Christianity's Jewish roots. ${ }^{8}$ When the research field of Israel Studies was strengthened within German universities in 2015 on the occasion of half a century of German-Israeli diplomatic relations, ${ }^{9}$ two junior academic positions were created in Heidelberg and Munich - and both were filled with graduates of ASF's Israel program. ${ }^{10}$

The history of ASF, ${ }^{11}$ the attitude of German Protestants and the German Left towards Israel, ${ }^{12}$ as well as the embeddedness of ASF volunteers in the politics of

4 For a number of introductory essays on the "Anti-Germans," see Moshe Zuckermann, ed., Tel Aviver Jahrbuch für Deutsche Geschichte 2005: Antisemitismus, Antizionismus, Israelkritik (Göttingen: Wallstein Verlag, 2005).

5 Kirchenamt der EKD, ed., Israel-Palästina: Eine Positionsbestimmung der Evangelischen Mittelost-Kommission (Hannover: EKD, 2009).

6 Gabriele Kammerer, In die Haare, in die Arme: 40 Jahre Arbeitsgemeinschaft "Juden und Christen” beim Deutschen Evangelischen Kirchentag (Gütersloh: Gütersloher Verlagshaus, 2001). 7 Evangelische Kirche in Deutschland (EKD), Gelobtes Land? Land und Staat Israel in der Diskussion: Eine Orientierungshilfe (Gütersloh: Gütersloher Verlagshaus, 2012).

8 For a detailed theological engagement with Israel Sunday by theologians close to ASF, see Wolfgang Raupach, ed., Weisung fährt von Zion aus, von Jerusalem Seine Rede: Exegesen und Meditationen zum Israel-Sonntag (Berlin: Aktion Sühnezeichen Friedensdienste, 1991).

9 Johannes Becke, "Land and Redemption: The Zionist Project in Comparative Perspective," Trumah 23 (2016): 1-13.

10 This includes Daniel Mahla, the current coordinator of the Center for Israel Studies at the Ludwig Maximilian University in Munich, and the author of this article.

11 Gabriele Kammerer, Aktion Sühnezeichen Friedensdienste: Aber man kann es einfach tun (Göttingen: Lamuv, 2008); Anton Legerer, Tatort: Versöhnung. Aktion Sühnezeichen in der BRD und in der DDR und Gedenkdienst in Österreich (Leipzig: Evangelische Verlagsanstalt, 2011).

12 Martin Kloke, Israel und die deutsche Linke (Frankfurt: Haag und Herchen, 1990); Gerhard Gronauer, Der Staat Israel (Göttingen: Vandenhoeck \& Ruprecht, 2013). 
post-war reconciliation, ${ }^{13}$ have all received ample scholarly attention. Despite its enormous impact on German-Israeli relations, however, the history of Aktion Sühnezeichen in Israel awaits its scholarly due. ${ }^{14}$ This chapter lays the ground for a systematic examination of ASF in Israel by presenting a framework for the study of Philozionism, atonement, and the politics of German guilt.

\section{Philosemitism and Philozionism: Young Germans playing Israelis?}

When it comes to the German-Israeli dimension of the larger Protestant-Jewish encounter, the affinity for Israel is frequently framed as part of the broader phenomenon of Philosemitism. ${ }^{15}$ With respect to studying the activity of ASF in Israel, though, a more adequate framework might be Philozionism, a type of affinity for Jewish nationalism which openly sympathizes with the Zionist motif of a radical break with the history, politics, and culture of the Ashkenazi Jewish Diaspora. Liliane Weissberg famously mocked the German Philosemitism of the bygone Klezmer craze as "young Germans [...] playing Jews." ${ }^{16}$ In examining the phenomenon of German Philozionism (whether within ASF or among the AntiGermans), we might adapt this phrase to speak of young Germans playing Israelis with regard to language, habitus, dress code, or an overall perspective on Jewish life and the Arab-Israeli conflict.

13 Christiane Wienand, "From Atonement to Peace? Aktion Sühnezeichen, German-Israeli Relations and the Role of Youth in Reconciliation Discourse and Practice," in Reconciliation, Civil Society, and the Politics of Memory, eds. Birgit Schwelling (Bielefeld: transcript, 2012), 201-35; Christiane Wienand, "Reverberations of a Disturbing Past: Reconciliation Activities of Young West Germans in the 1960s and 1970s," in Reverberations of Nazi Violence in Germany and Beyond, eds. Stephanie Bird et al. (London: Bloomsbury, 2016): 223-50.

14 For an overview, see Jörn Böhme, "Die Arbeit der Aktion Sühnezeichen/Friedensdienste in Geschichte und Entwicklung,” in 20 Jahre Deutsch-Israelische Beziehungen, ed. Karlheinz Schneider (Berlin: Deutsch-Israelischer Arbeitskreis für Frieden im Nahen Osten, 1985: 137-50; Marom, “'On Guilt and Atonement.' Aktion Sühnezeichen Friedensdienste and Its Activity in Israel”; Aktion Sühnezeichen Friedensdienste, 50 Jahre Aktion Sühnezeichen Friedensdienste in (Berlin: Aktion Sühnezeichen Friedensdienste, 2011).

15 Adam Sutcliffe and Jonathan Karp, "Introduction: A Brief History of Philosemitism," in Philosemitism in History, eds. Jonathan Karp and Adam Sutcliffe (Cambridge and New York: Cambridge University Press, 2011): 1-26.

16 Liliane Weissberg, Reflecting on the Past, Emvisioning the Future: Perspectives for GermanJewish Studies (New York: Leo Baeck Institute, New York, and German Historical Institute, Washington, 2003), 12. 
While Philosemitism and Philozionism rely on a similar set of textual and historical symbols in their perception of "the Jews as a resolutely distinct people, with distinctively admirable characteristics," 17 they tend to draw rather different conclusions. At the risk of over-simplification, one might suggest the following typology: Philosemites study the Talmud (through the eyes of Daniel Boyarin), but Philozionists read the Hebrew Bible (through the eyes of David Ben Gurion) ${ }^{18}$; Philosemites admire Diasporic statelessness, but Philozionists celebrate state-making and military prowess; Philosemites learn Aramaic and Yiddish, but Philozionists study modern Hebrew; finally, Philosemites dream of converting to Judaism (the Orthodox stream, to make it more authentic), but Philozionists mimic the traits of Israeliness (secular Ashkenazi Israeliness, to make it more prestigious).

For an organization whose very name carries the loaded term 'atonement,' the salient phenomenon of conversions to Judaism as a form of Vergangenheitsbewältigung (overcoming the past) ${ }^{19}$ might not be terribly surprising. ${ }^{20}$ Conversions to Zionism (or Anti-Zionism, for that matter) have proved to be more problematic, however, both for political and theological reasons. In the context of ASF's activities in Israel, engagement with the question of Philozionism left an enduring impact on the organizational culture of the organization. Countering the romantic Christian Zionism of ASF's founder, Lothar Kreyssig, the Israel volunteers on the ground quickly developed an abiding organizational culture of sarcasm (with significant traces of Israeli humor). Second, in response to the

17 Sutcliffe and Karp, "Introduction: A Brief History of Philosemitism," 7.

18 In this context, left-wing German Protestantism developed its own tradition of studying the Talmud, but in a decidedly Jewish-Israeli setting, a close entanglement of Philosemitism and Philozionism. As a critical intervention against Christian Anti-Judaism (often based on distorted readings of the Talmud), the study program Studium in Israel (Studies in Israel) has brought more than 600 German students of Protestant theology to Israel to study Rabbinic literature at the Hebrew University of Jerusalem. Unsurprisingly, the study program has a strong Sühnezeichen connection: Michael Krupp, one of its founders, was the former head of the ASF office in Jerusalem. The study program also produced an influential series of preaching material that deals with Christian-Jewish relations; see Wolfgang Kruse, ed., Predigtmeditationen im christlich-jüdischen Kontext: Zur Perikopenreihe I (Neuhausen: Kruse, 2002).

19 On conversions to Judaism as Vergangenheitsbewältigung see Barbara Steiner, Die Inszenierung des Jüdischen: Konversion von Deutschen zum Judentum nach 1945 (Göttingen: Wallstein Verlag, 2015), chapter 5.

20 For the conversion account of Christel Eckert (Michal Evenari), who belonged to the first cohort of Aktion Sühnezeichen volunteers and was married to an Israeli, see Michal Evenari, "The Story of a Life: From Germany to Israel," Chabad, 2008, http://.www.chabad.org/theJewish Woman/article_cdo/aid/704922/jewish/The-Story-of-a-Life.htm (last accessed September 29, 2017). 
radical critique of ASF's one-sided identification with the Zionist project (both real and imagined) which was voiced by Aktion Sühnezeichen volunteers from the New Left, ASF's leadership attempted to promote an ethos of 'critical solidarity' with Israel, based on the writings of the left-wing theologian Helmut Gollwitzer (1908-1993). ${ }^{21}$

ASF's culture of sarcasm may seem somewhat puzzling; after all, the organization is known for its nuanced and theologically complex position towards German memorial culture. ${ }^{22}$ In a spirit of camaraderie, former volunteers jokingly refer to one another as "fellow atoners" (Mitsühner), and former Israel volunteers are known as "first-class atoners" (Edelsühner). Such sarcastic humor seems to have emerged from the gap between the organization's sublime theology of atonement and the mundane reality of difficult volunteer work done in nursing homes, kindergartens and Holocaust memorial sites. Among the Israel volunteers, however, this dark wit, which was already articulated by the very first cohort, might also be understood as backlash to the organization's guiltdriven Philozionism. The letters of Lothar Kreyssig from that period, for instance, depict Israeli state formation from a decidedly Christian Zionist perspective, with German volunteers playing the role of the biblical spies (Numbers 13:1-33) and the eschatological ingathering of the gentiles (Isiaiah 56: 6-7). Kreyssig portrayed the first cohort of Israel volunteers as the "first reconnaissance patrol, with which we will arrive in Israel after a long and arduous wandering across the mountain ridges of German guilt."23 When the volunteers had to wait in the Netherlands before being allowed into Israel, Kreyssig likened their journey to the biblical wandering across the desert, "when the People of Israel lived in tents for forty years on the way to the conquest of the Land (Landnahme). What a deep reference to the end of all ways, that we can now accompany the People of God on the way to its final conquest of the land!"24

21 Helmut Gollwitzer, Vietnam, Israel und die Christenheit (Munich: Christian Kaiser Verlag, 1967). On ASF’s activities in Israel, see esp. Helmut Gollwitzer, "Zur Israel-Arbeit der Aktion Sühnezeichen” (February 1977), EZA 97/719.

22 Christian Staffa, “Die 'Aktion Sühnezeichen': Eine protestantische Initiative zu einer besonderen Art der Wiedergutmachung," in Nach der Verfolgung: Wiedergutmachung nationalsozialistischen Unrechts in Deutschland?, eds. Hans Günther Hockerts and Christiane Kuller (Göttingen: Wallstein-Verlag, 2003): 139-56.

23 Letter from Lothar Kreyssig to Harald Schlagowski, January 28 1962, EZA 19/735.

24 Letter from Lothar Kreyssig to Eleonore Dannemann, January 10 1962, EZA 19/735. For more examples of Kreyssig's idiosyncratic theology of atonement, see Konrad Weiß, Lothar Kreyssig: Prophet der Versöhnung (Gerlingen: Bleicher Verlag, 1998), chapter 18 - including the idea to have Aktion Sühnezeichen volunteers build a temple for Jews, Christians and Muslims in Jerusalem or to establish a 24/7 prayer team of volunteers at Yad Vashem. 
Yet it did not take long for the initial romanticism of encountering the Land of Israel from the deck of a ship in Haifa to be replaced by an acid wit. The first cohort referred to itself as an "atonement team" (Sühnemannschaft) and an "atonement family" (Sühnefamilie) guided by their "atonement father" (Sühnevater, the group's pastor). Volunteers who picked potatoes for up to ten hours each day were said to be engaging in "real atonement" (echt zu sühnen) while female volunteers or "atonement girls" (Sühnemädchen) who fell ill were described as "incapacitated to atone" (sühnekampfunfähig). ${ }^{25}$ Many of the terms appear already crossed out in the original manuscript, and none made it into the official publication of parts of the diary of the first cohort in Ansgar Skriver's book on Aktion Sühnezeichen. ${ }^{26}$ The self-deprecating humor, however, prevailed: decades later, the volunteer journal Memrachit would feature mock advertisements poking fun at Israel as the "atonement paradise," pretended to offer Tshirts with the logo "Atone with us. Atoning is fun," and inquired of its readers, "Have you atoned today?"27

While such satire might have helped ASF volunteers deal with the disillusionments of romantic Philozionism, it was no match for the ideological battles that came to shape the organization's work in Israel after the Six Day War in 1967. When ASF opened its doors to conscientious objectors in 1969, an increasing number among the volunteers arrived with affiliations to the New Left and were no longer willing to read the "conquest of the Land" (Landnahme) in the occupied territories in light of biblical prophecy. Political violence began to affect the organization's activities, and when a Palestinian terrorist attacked an ASF bus in Nablus in 1976 with a nail bomb, two young Germans were killed and many more were injured. ${ }^{28}$ The traumatic experience made a strong impression on future generations of volunteers, but the terror attack did not seem to disillusion those volunteers who openly identified with the Palestinian cause. Volunteer projects that focused on the Palestinian Arab minority in Israel, in particular, produced vocal opponents of Israel's settlement policy. ${ }^{29}$ In the first issue after the outbreak of the First Intifada, the volunteer journal Memrachit printed

25 EZA 19/735.

26 Ansgar Skriver, Aktion Sühnezeichen: Brücken über Blut und Asche (Stuttgart: Kreuz-verlag, 1962), $120-38$.

27 Memrachit 1-3, EZA 19/1868.

28 Kammerer, Aktion Sühnezeichen, 159-62.

29 For publications by former ASF volunteers on the occupied territories, see Jan Metzger, Martin Orth, and Christian Sterzing, Das ist unser Land: Westbank und Gaza-Streifen unter israelischer Besatzung (Bornheim-Merten: Lamuv, 1980); Dieter Bednarz und Michael Lüders, Palästina Protokolle: Bestandsaufnahme und Perspektive (Hannover: Fackelträger-Verlag, 1981). 
its name in Arabic instead of in Hebrew letters, published legal advice in case of being arrested at demonstrations, and included an angry accusation directed at the Israel desk at ASF headquarters:

Honestly speaking, I am quite disappointed by ASF's Israel policy. ASF invokes two elements that are important to me: The 'Confessing Church' and the phrase 'learning from history'. You know the situation in Israel. Would you disagree when I say that there is racial discrimination, 'highly arbitrary' 'democratic rights', torture in the prison system and racial prejudice? 'Learning from history': How many people [still] need to be arrested, tortured, shot down before ASF shows its true colors? I'm not calling on you to send us stones or Molotov cocktails. Like almost all the volunteers in the Arab sector, I'm finally calling for more clear-cut statements and a more definitive advocacy for the Palestinian cause. ${ }^{30}$

\section{From Critical Solidarity to a Theology of Israel}

No such clear-cut statement would arrive from Berlin. On the contrary, in response to the First Intifada, ASF published a long and carefully worded open letter addressed to "all those in the Federal Republic who follow the news from Israel and the occupied territories with great concern and ask themselves what to do." ${ }^{31}$ Framed as a German response to a much more radical statement by Israeli peace organizations (which criticized the "wide-spread unconditional loyalty towards the State of Israel" and called for a struggle against "the moral and physical decay of Israeli society" ${ }^{32}$ ), ASF's missive showed all the hallmarks of the 'critical solidarity' with Israel which the Aktion Sühnezeichen leadership had begun to promote in the 1970s as a response to an influx of New Left volunteers: a conflicted sense of solidarity with both sides, a rejection of simplifications, and an ethics of responsibility rooted in both the history of German guilt and leftwing Protestantism. ${ }^{33}$

30 Memrachit December 1987, EZA 19/1868.

31 Ulrike Berger et al., Offener Brief an alle, die in der Bundesrepublik die Nachrichten aus Israel und den besetzten Gebieten mit Sorge verfolgen und sich fragen, was sie tun können (Berlin: Aktion Sühnezeichen Friedensdienste, 1988).

32 "Appell an die Freunde Israels," ibid., 8; quoting Jesch Gvul, Ha Schana ha 21, and Dai le Kibusch. "Appell an Die Freunde Israels.” In Offener Brief an alle, die in der Bundesrepublik die Nachrichten aus Israel und den besetzten Gebieten mit Sorge verfolgen und sich fragen, was sie tun können, edited by Ulrike Berger, Jörn Böhme, Dietrich Gaede, Bernhard Krane, and Heribert Krane, 8. Berlin: Aktion Sühnezeichen Friedensdienste, 1988.

33 For earlier ASF statements on the topic, see Volkmar Deile, Heiner Holland, and Johannes Müller, "Richtlinien der Arbeit der Aktion Sühnezeichen/Friedensdienste in Israel," Zeichen 2 
In contrast to the Christian Zionism of Pietist and Evangelical origins (with its own Israel-based volunteer organization), ${ }^{34}$ this left-wing Protestant Theology of Israel was decidedly non-messianic, showing a clear sympathy for the socialist ideals of the kibbutz. Thus, in a speech entitled "Israel - and Us" (Israel - und wir), held in Berlin in 1958 after returning from a trip to Israel, ${ }^{35}$ Helmut Gollwitzer famously identified three "moments" - that is, perspectives - on the State of Israel: from a moral perspective, "[every] German who travels to Israel should be clear: every Jew who lives today lives not because of us, but in spite of us [...] in spite of me!" From a theological perspective, the renewal of Jewish life in the Land of Israel/Palestine could lead to a renewal of biblical hermeneutics and Christian-Jewish dialogue; after all, "anyone who deals with Israel must - like it or not - be a theologian.” Finally, from a sociological perspective, Gollwitzer argued that Israel (in sharp contrast to the Federal Republic of Germany) represented an example of a "non-restorative social structure," a form of socialist awareness crystallized in the "phenomenon of kibbutzim."36

As an expression of this Gollwitzer-style 'critical solidarity,' the ASF open letter from 1988 emphasizes the "specific German background [...] of the Shoah" and its consequence of "a strong need for security that is felt by many Jews inside and outside of Israel," only to contrast this with "the need for security by the Palestinians, in whose history the flight and expulsion of 1948 known as 'al-Nakba' (the catastrophe) is a central frame of reference." ${ }^{37}$ While underlining the self-understanding of Zionism as "the national liberation movement of the Jewish people" and the "non-colonial character" of the Arab-Israeli conflict, the text sheepishly admits "colonial aspects in Israel's development, concerning, for instance, the appropriation of lands and the economic linkage between the occupied territories and the heartland." ${ }^{38}$ In addition, after rejecting the claim that Zionism represents "a form of racism," the letter goes on to acknowledge "racist thought and actions" in Israel, including the "almost total lack of rights

(1977): 30 -1; “Präambel für die Arbeit in Israel,” Zeichen, 9:1 (1981): 11-2; “Grundsätze der Israelarbeit," Zeichen, 14:2 (1986): 16-7.

34 Andrea Schneider, "Hagoshrim - Die Brückenbauer: Freiwilligendienst in Israel," www.rundfunk.de, 2016, https://rundfunk.evangelisch.de/kirche-im-radio/am-sonntagmorgen/ hagoshrim-die brueckenbauer-7826 (last accessed August 28, 2018).

35 Helmut Gollwitzer, Israel - und wir (Berlin: Lettner, 1958).

36 All quotations according to W. Travis McMaken, “'Shalom, Shalom, Shalom Israel!' Jews and Judaism in Helmut Gollwitzer's Life and Theology,” Studies in Christian-Jewish Relations 10:1 (2015): 1-22, here at 13-5.

37 Ibid., 3.

38 Ibid., 4. 
and the oppression of the Palestinians in the occupied territories." 39 After strongly condemning the claim to a "special German responsibility towards the Palestinians" as "the victim's victim," 40 the text also rejects the temptation to "wholeheartedly take a position for one of the two sides. Such wholehearted support could only refer to both peoples' right to exist in Israel/Palestine."41 Even the text's concluding call for action appears exceedingly well-balanced by criticizing West Germany's “military cooperation with Israel and the Arab states, which makes it harder to find a political solution to the conflict."42

This carefully constructed equidistance crumbled under the shock of an intense polarization in the German Left during the First Gulf War and the two Palestinian intifadas. DIAK (Deutsch-Israelischer Arbeitskreis für Frieden im Nahen Osten), the left-wing offshoot of the more mainstream German-Israeli Society (DIG, Deutsch-Israelische Gesellschaft), took a sharp turn towards a more radicalized critique of Israel and the Zionist project. ${ }^{43}$ Aktion Sühnezeichen, for its part, increasingly returned to its Philozionist roots, not least by abandoning all volunteer projects that centered exclusively on Israel's Palestinian Arab minority in 1994. This ideological shift comes into stark relief when one reads ASF publications dedicated to the celebration of Israel Sunday: in 1995, for instance, the brochure contained an interview with Eliezer Feiler, a member of the Israeli Communist Party who had long been responsible for the party's external relations. ${ }^{44}$ In its original form, the interview had been published by two ASF volunteers deployed in the "Arab sector," ${ }^{45}$ preceded by the following tendentious introduction:

The political activist Feiler [...] repeatedly witnessed wrongful Jewish actions against Arabs and had to realize that chauvinism and national arrogance are not typically German char-

39 Ibid., 5.

40 In another example of ASF sarcasm, during the author's stay in Israel (2001-2002), a German Protestant senior volunteer was jokingly referred to as "the victims' victims' victim" after a group of young Palestinians in Jerusalem had stolen his wallet.

41 Ibid., 7.

42 Ibid., 8 [emphasis added].

43 Martin Kloke, "In aller Freundschaft: 50 Jahre Deutsch-Israelische Gesellschaft," haGalil.com, 2016, http://www.hagalil.com/2016/03/deutsch-israelische-gesellschaft/ (last accessed October 9, 2017).

44 Yossi Melman, “He saw Red,” Ha’aretz, 2004, https://www.haaretz.cim/he-saw-red-1.111779 (last accessed October 9, 2017).

45 Dieter Bednarz and Michael Lüders, Blick zurück ohne Hass: Juden aus Israel erinnern sich an Deutschland (Cologne: Bund-Verlag, 1981), 116-39. 
acteristics: Ominously, the attitude of many Jews in Israel towards the Arabs resembles in many respects the German position towards the Jews in the time of National Socialism. ${ }^{46}$

In the 1995 ASF brochure for Israel Sunday, this passage disappeared. Nonetheless, while keeping quiet about Eliezer Feiler's affiliation with the Israeli Communist Party, the interview still contains the passage which had attracted the attention of its original publishers: "The Germans uncritically adopted the propaganda depiction [of the Jew], because a majority of Germans had no idea what a Jew was supposed to be. Here [in Israel] the same thing happens when it comes to the Arabs." ${ }^{47}$

ASF's publications for Israel Sunday from recent years are decidedly less open to a radical critique of Israel and the Zionist project. Consider, for example, the content of the Israel Sunday brochures from 2003 until 2017, which discussed the politics of Palestinian nationalism, including BDS $^{48}$ and the Kairos Palestine Document. ${ }^{49}$ However, although the texts featured Jewish-Israeli voices (often from the moderate Israeli left), during the same period only a single Palestinian author appeared in the brochures, tellingly to discuss Jerusalem from a Muslim (not, say, Palestinian) perspective. ${ }^{50}$

While the collections of short texts include highly critical discussions of Evangelical Christian Zionism, ${ }^{51}$ the overarching legacy of Protestant Philozionism is unmistakable. For instance, a liturgy suggestion for Israel Sunday from 2008 describes the establishment of the State of Israel as "God's sign of protection (Gottes Zeichen seiner Bewahrung) [of his people] after and within a history

46 Ibid., 116.

47 Aktion Sühnezeichen Friedensdienste, Wenn die Propheten aufständen ...: Handreichung zum Israel-Sonntag 1995 (Göttingen: Aktion Sühnezeichen Friedensdienste 1995), 39.

48 Christian Staffa, "Was tun mit der Kampagne Boykott, Desinvestition, Sanktionen?," in Israelsonntag 2015: Denkt nicht, ich sei gekommen, die Tora und die Propheten außer Kraft zu setzen (Berlin: Aktion Sühnezeichen Friedensdienste, 2015), 25-28.

49 Hanna Lehming, Und es ist doch ein Kairos! (Berlin: Aktion Sühnezeichen Friedensdienste 2011).

50 Abdallah Hajjir, “Jerusalem aus muslimischer Perspektive," in Israelsonntag 2012: Jerusalem - Niemand wird dich noch "Verlassene” nennen (Jesaja 62, 4) (Berlin: Aktion Sühnezeichen Friedensdienste, 2012), 37-38. In contrast to the title, the text itself does contain references to Jerusalem from a Palestinian perspective.

51 Martin Kloke, “Christliche Zionisten - Eine kritische Darstellung,” in Israelsonntag 8. August 2010. “Wünschet Jerusalem Segen ...” Psalm 122, 77-87 (Berlin: Aktion Sühnezeichen Friedensdienste, 2010. 
of homelessness and hardships among the nations, including Christendom." 52 In the confession of sins, the text recommends asking for forgiveness for the fact that "we failed to recognize it as a sign of your faithfulness when [your people] returned to live within its borders as an independent state." 53 The prayers of intercession ask God to "sharpen our attention for anything which appears as an indignant criticism of Israel (Israelkritik), but is in reality anti-Jewish (judenfeindlich)." In a somewhat curious phrasing that seems undecided whether the divine promise ends at the Green Line, the prayer concludes by requesting divine protection "for the Jewish communities here and the Israeli cities and settlements over there." 54

The most recent position paper on ASF's activities in Israel from 2014, written by Bernhard Krane, the head of the ASF Israel desk, aptly captures this return to the left-wing Christian Philozionism of Helmut Gollwitzer and his disciple Friedrich-Wilhelm Marquardt. ${ }^{55}$ With clarity that would have been unthinkable throughout Aktion Sühnezeichen's period of anxious equidistance, the position paper notes:

For theological and political reasons, Aktion Sühnezeichen fights for the belief that a special bond links the People of Israel (Am Israel) and the Land of Israel (Erez IsRaEL) and that the modern State of Israel has the right to exist as the nation-state of the Jewish People. Such a pro-Zionist position creates both common ground as well as divisions in ASF's cooperation with other civil society groups and parties. [...] ASF's Theology of Israel is based on the continuing relevance of God's covenant with the People of Israel and the Divine Promise of the Land. ${ }^{56}$

52 Helmut Ruppel, "Liturgie Für den Gottesdienst am 10. Sonntag nach Trinitatis. 'Israel 1948 2008'." in Israelsonntag 2008 ...und so wird ganz Israel gerettet werden, wie geschrieben steht: 'Aus Zion wird kommen der Retter.' (Brief an die Gemeinde in Rom, 11,26) (Berlin: Aktion Sühnezeichen Friedensdienste, 2008), 18-22, here at 18.

53 Ibid., 19.

54 Ibid., 21.

55 Friedrich-Wilhelm Marquardt, Die Juden und ihr Land (Hamburg: Siebenstern-TaschenbuchVerlag, 1975).

56 Bernhard Krane, Grundsätzliches zur ASF-Israelarbeit (Berlin: Aktion Sühnezeichen Friedensdienste, 2014).) 


\section{Atonement as At-One-Ment: From Christian to Post-Christian Philozionism}

How exceptional is the history of ASF in Israel? Zygmunt Bauman reminds us that positive and negative exceptionalism are both fruit of the same tree. He depicts the long history of Western exceptionalism towards the Jewish people as "Allosemitism," "the practice of setting the Jews apart as people radically different from all the others, needing separate concepts to describe and comprehend them and special treatment in all or most social intercourse." ${ }^{" 57}$ Thus, German Protestant Philozionism should not be studied in isolation from its counterimage, namely, a theologically grounded Antizionism within the same milieu: resentment towards Zionism and the State of Israel has a long history within the German Protestant Church, especially within left-wing Protestantism. ${ }^{58}$ The level of German Protestant investment (both financially and emotionally) into the community of barely 3,000 Palestinian Arab Lutherans in the Holy Land, for instance, far outstrips their numbers and relevance for the declining minority of Palestinian Arab Christians. Consequently, the study of both Protestant Philozionism and Antizionism needs to be integrated into a broader history of Allozionism, ${ }^{59}$ an exceptionalist understanding of Jewish nationalism which, in the German case, goes back to Johann Gottfried Herder's fascination with the ancient Hebrews. ${ }^{60}$

Such a historicizing approach ought to be applied as well to the phenomenon of German guilt and Sündenstolz (sinner's pride): research on the GermanJewish-Israeli conundrum still tends to be approached as a densely entangled cluster of exceptionalism, demarcated by a sense of Jewish nationhood as an $e x-$ ceptional people, the Shoah as an exceptional crime perpetrated by the Germans, and finally, the State of Israel as an exceptional state. Paradoxically, the recent establishment of separate chairs and research institutes for the study of the

57 Zygmunt Bauman, “Allosemitism: Premodern, Modern, Postmodern,” in Modernity, Culture and "the Jew," eds. Bryan Cheyette and Laura Marcus (Cambridge: Polity Press, 1998): 143-56, here at 143.

58 For a concise overview, see Martin Kloke, "Deutsche Protestanten und der Sechstagekrieg 1967. Eine Biblanz nach 50 Jahren,” Compass-Infodienst, 2017, https://www.compass-infodi enst.de/Martin-Kloke-Deutsche Protestanten-und-der-Sechstagekrieg-1967.15867.0.html (last accessed October 11, 2017).

59 Johannes Becke, "Beyond Allozionism: Exceptionalizing and de-Exceptionalizing the Zionist Project," Israel Studies 23:2 (2018): 168-93.

60 Ofri Ilany, In Search of the Hebrew People: Bible and Nation in the German Enlightenment (Bloomington, N: Indiana University Press, 2018). 
State of Israel and the Holocaust in German academia has the potential to further entrench this phenomenon, unless their teaching and research are closely integrated into a comparative research agenda.

In the case of ASF, such an approach might explore, for instance, linkages between transgenerational guilt-driven identification with the victims and similar historical processes. To put it in the sarcastic parlance common among former ASF volunteers: how does German Edelschuld (first-class guilt) and German Edelsühne (first-class atonement) differ from ordinary white guilt? What distinguishes guilt-driven German converts to Judaism from figures like Rachel Dolezal, the famous "trans-racial" convert to blackness? ${ }^{61}$ What are the commonalities and differences between the many, many German converts pushing into Jewish Studies and Rabbinical Studies, and what Native American scholars refer to as ethnic fraud, namely, the curious phenomenon of white people pushing into Native American Studies based on spurious claims to distant Native American ancestry ${ }^{62}$

To evade the trap of exceptionalism, the entanglement of guilt and redemption in the German-Israeli and the Protestant-Jewish encounter needs to be studied as part of a broader history of emotions of the post-colonial and increasingly post-Christian West. Such a comparative and theory-guided approach might be usefully informed by the dynamics of vicarious ethnicity as a form of atonement, or, in the words of the psychoanalyst Irwin Rosen, "atonement as at-one-ment." For Rosen, atonement is an "identification with the fantasized victim of one's sadism," and "this identification constitutes the atonement (or at-one-ment) experience in which, magically, the aggressor seeks forgiveness, by becoming onein-suffering with his victim." ${ }^{63}$ Rosen's psychoanalytic model captures two distinct processes of atonement as at-one-ment, depending on the type of identification with the victim: concordant and complementary. In the concordant model of identification with the victim, the "guilty and self-accusatory concordant atoner" seeks to repair "that aspect of himself that has been identified with the victim," ${ }^{64}$ frequently through acts of reparation. Unlike these "repairers," ${ }^{65}$ their counterparts (who follow the complementary type of atonement) struggle with

61 Rachel Dolezal and Storms Reback, In Full Colour: Finding My Place in a Black and White World (Dallas: BenBella Books, 2017).

62 Elizabeth Cook-Lynn, “Taku Inichiapi? What's in a Name?,” in A Separate Country: Postcoloniality and American Indian Nations (Lubbock: Texas Tech University Press, 2012), 123-32. 63 Irwin C. Rosen, “The Atonement-Forgivenness Dyad: Identification with the Aggressed," Psychoanalytic Inquiry 29 (2009): 411-25, here at 414.

64 Ibid., 412.

65 Ibid., 420. 
the "imaginatively enhanced, projectively ascribed retaliation of the vengeful victim who is now endowed with the same malevolence as that which impelled the abuser's original attack" ${ }^{66}$ - as "embracers of suffering." 67

If we apply this typology to the German politics of guilt, the Christian Philozionism of Aktion Sühnezeichen might be considered a concordant type of atonement, based on the idea of atonement as reparation. In contrast, the post-Christian Philozionism of the so-called "Anti-Germans" (Antideutsche) appears to be a complementary type, namely, atonement as suffering and vengeance. In other words, concordant atoners are drawn to acts of repentance, including the option of ideological, religious, and even ethnic conversion, as its most radical form. Complementary atoners, for their part, seek a projection screen for their fantasies of self-harm, or, as the Anti-Germans have put it in reference to the bombing of Dresden: "Bomber Harris - do it again."68

Of course, the two types of atonement are closely intertwined. The entanglement of Christian and post-Christian Philozionism in particular stands out in the writings of the late Eike Geisel, another former ASF volunteer in Israel. After publishing Nathan Weinstock's Le sionisme contre Israël in German, ${ }^{69}$ Geisel later became an important inspiration for Philozionists in the German Left and an acerbic critic of the self-serving German culture of faux atonement, including conversions to Judaism..$^{70}$ As the case of Eike Geisel shows, the ideological production of the Anti-Germans and their intellectual forebears can hardly be reduced to provocative statements, puzzling acts of self-flagellation, and the characteristic personality disorders of "compulsive confessors"71 and "atonement addicts." 72 For scholars of Jewish-Protestant relations however, the shift from Sühnezeichen (sign of atonement) to Antideutsche (Anti-Germans) might indicate an intriguing theological movement: like other varieties of white guilt, the

\footnotetext{
66 Ibid., 412.

67 Rosen, “The Atonement-Forgivenness Dyad," 420.

68 For an insightful case study of left-wing Israeli bewilderment at the phenomenon of the AntiGermans, see Amira Hass, "Korban Mi-She-Korban Acharon (He Who Is the Last Victim Is the True Victim),” Ha'aeretz, 2004, http://www.haaretz.co.il/1.957024.

69 Nathan Weinstock, Das Ende Israels? Nahostkonflikt und Geschichte des Zionismus, eds. Eike Geisel and Mario Offenberg (Berlin: Verlag Klaus Wagenbach, 1975).

70 Eike Geisel, "Deutsche Seelenwanderungen: Rückblick auf eine zehnjährige deutsch-jüdische Verwechslungskomödie,” in idem, Die Banalität des Guten: Deutsche Seelenwanderungen (Berlin: Edition Tiamat, 1992), 9-34.
}

71 Rosen, “The Atonement-Forgivenness Dyad," 421.

72 Ibid., 420. 
Anti-German ideology of a "revenge against the self" 73 resonates with the basic template of post-Christianity - all of the guilt, with none of the forgiveness.

\section{Conclusion}

As the case of the Temple Society (Tempelgesellschaft) demonstrates, the German Protestant presence in the Land of Israel predates both the State of Israel and the institution-building of the New Yishuv. ${ }^{74}$ In the long history of German Protestant engagement with Jewish nationalism, the activities of Aktion Sühnezeichen Friedensdienst in Israel reflect a compelling combination of paradoxes: a theology of Israel that is decidedly left-wing, an ethics of atonement which coexists with an entrenched culture of sarcasm, and a complex legacy of Philozionism that stretches all the way from Christian Zionism to the 'critical solidarity' of a strict equidistance, while sometimes foreshadowing the naïve Anti-German enthusiasm for all things Israeli.

For the study of contemporary Jewish-Protestant relations, the history of ASF is a vivid reminder that the Zionist project not only represents a rupture for Jewish history, but also for interfaith relations. Hence, both the most intense forms of contemporary Protestant sympathy and antipathy for the Jewish experience are no longer shaped by Diasporic statelessness, but by Zionist state formation in the Land of Israel. Especially in the German case, such a study of Protestant Philozionism and Antizionism should not be limited to the fields of theology and church history, but instead contribute to a broader history of emotions of the post-colonial and post-Christian West, with a special focus on the emotional politics of white guilt.

73 Ibid., 423.

74 For an intriguing case study of counterfactual history which explores what a German Protestant state project in the Land of Israel might have looked like, see Derek Jonathan Penslar, "What If a Christian State Had Been Established in Modern Palestine?," in What Ifs of Jewish History: From Abraham to Zionism, ed. Gabriel D. Rosenfeld (Cambridge and New York: Cambridge University Press, 2016): 142-65. 
